\title{
KONFLIK TANAH SURAT IJO DI SURABAYA (SEBUAH PERSPEKTIF TEORETIK-RESOLUTIF) Sukaryanto*
}

\begin{abstract}
The control/ownership of land in Surabaya is marked by the unique phenomenon of surat ijo; many residents in the municipalities life on state land. Entering Reform Ere (1999), most of the occupants were no longer abide to the existing regulations. Furthermore, solidarity within community of "tanah surat ijo" arises, and has led them to establish their own mass organization and fight for hak milik (HM, land ownership rights) over the land they occupy. It is thus unsurprising that conflict of interest has occurred between the two. Various efforts to resolve this conflict have been undertaken, including mediation and a civil suit, but these have been unsuccessful to date. Similarly, the enactment of Peraturan Daerah No. 16 Tahun 2014 (Surabaya Municipal By law No. 16 of 2014) was unable to resolve the conflict. This paper attempts to understand and explain the context of land control, ownership, and conflict over "tanah surat ijo" in Surabaya. As conclusion, that the system of "tanahsurat ijo"-is a transformation of the colonial land rent system-has affected all aspects (be they social, economic political, cultural, or psychological) of its residents lives. Besides that, to promote conflict resolution, there must be a transformation in "tanah surat ijo" system; this requires the involvement, cooperation, and coordination between relevant ministries.
\end{abstract}

Keywords:surat ijo, state land, resolution, conflict, Surabaya

Intisari: Penguasaan/pemilikan tanah di Surabaya ditandai fenomena unik tanah surat ijo, yakni permukiman sebagian warga kota di atas tanah negara. Memasuki era Reformasi (1999) sebagian besar warga penghuni tidak lagi patuh pada peraturan yang berlaku. Bahkan, timbul solidaritas komunitas warga pemukim tanah surat ijo yang kemudian membentuk organisasi massa melakukan upaya untuk memperoleh hak milik atas tanahnya. Tak pelak, terjadilah konflik sosial antara keduanya. Berbagai upaya resolusi telah dilakukan mulai mediasi hingga di meja peradilan tertinggi belum bisa menyelesaikan. Demikian pula, pemberlakuan Peraturan Daerah No. 16 Tahun 2014 tentang pelepasan asset pun belum dapat mewujudkan resolusi konflik. Tulisan ini mencoba untuk memahami dan menjelaskan konteks penguasaan, kepemilikan, dan konflik atas tanah surat ijo di Surabaya. Sebagai simpulan, keberadaan tanah surat ijo -sebagai jelmaan sistem sewa tanah pada era kolonialtelah menimbulkan dampak di semua segi kehidupan warga penghuni, mulai aspek sosial, ekonomi, politik, hingga budaya/ psikologi. Selain itu, di dalam kerangka upaya mencapai resolusi konflik diperlukan perubahan system tanah surat ijo, untuk itu perlu keterlibatan, kerjasama, dan koordinasi antara beberapa kementerian yang terkait.

Kata kunci: surat ijo, tanah negara, resolusi, konflik, Surabaya

\section{A. Pendahuluan}

Pengertian tanah surat ijo adalah permukiman rakyat di atas tanah negara dengan legalitas surat Izin Pemakaian Tanah (IPT). Surat ijo merupakan

* Penulis adalah kandidat doktor Ilmu Sejarah pada Program Studi Ilmu-Ilmu Humaniora Program Pasca Sarjana FIB UGM. E-mail: skyt_unair@yahoo.co.id. fenomena hubungan kontraktual antara dua pihak yang saling membutuhkan, yakni warga penghuni dan Pemerintah Kota Surabaya. Seiring berjalannya waktu yang ditandai perubahan peraturan tentang pertanahan, timbullah hambatan interaksi antar keduanya, timbul situasi saling merasa sebagai pihak yang paling berhak atas tanah surat ijo yang berlanjut pada timbulnya konflik interest antar keduanya.

Semula, legalitas menyewakan tanah-tanah 
negara hasil konversi tanah hak Barat itu dimulai sebelum pemberlakuan UUPA 1960, kemudian diformalkan pada tahun 1971, ketika diberlakukan Surat Keputusan (SK) DPR-GR Daerah Kotamadya Surabaya No. o3E/DPRGR-KEP/1971 tertanggal 6 Mei 1971 tentang Sewa Tanah. Pada masa selanjutnya, ketika sudah banyak tanah hak Barat yang dikonversi menjadi status Hak Pakai (HP) dan Hak Pengelolaan (HPL), maka konsep/istilah sewa tanah di atas tanah negara itu menjadi kurang tepat, bahkan tidak bisa dibenarkan; karena yang berhak menyewakan tanah adalah pemilik tanah atau pemegang sertifikat Hak Milik (HM). Kemudian, untuk menyiasati hal itu, diterbitkan Peraturan Daerah Kotamadya Daerah Tingkat II Surabaya No. 22 Tahun 1977 tentang Pemakaian dan Retribusi Tanah yang Dikelola oleh Pemerintah Kotamadya Daerah Tingkat II Surabaya, sejak saat itu Izin Sewa Tanah berubah menjadi Surat Izin Pemakaian Tanah (IPT).

Berdasarkan pembaharuan dasar legalitas, terjadi penggantian istilah "sewa tanah" menjadi "pemakaian tanah", dua istilah tersebut sebenarnya mempuyai makna yang sama, yakni mewajibkan warga penghuni membayar sejumlah uang tertentu (retribusi) setiap tahun pada Pemerintah Kota Surabaya. Di kalangan warga penghuni menyebut surat IPT yang bersampul warna hijau itu sebagai surat ijo (surat hijau). Sebutan itu terus berkembang di kalangan warga Kota Surabaya, bahkan bisa dikatakan telah melegenda sebagai trade mark pengelolaan tanah negara di Surabaya.

Dalam konteks diatas yang menjadi pertanyaan adalah, apakah ketidaklaziman atau keunikan itu akan terus berlanjut tanpa ujung? Bilamana berlanjut, tidakkah disadari bahwa hal itu bermakna sebagai bersinambungnya rasa ketidakadilan di kalangan warga penghuni tanah surat ijo, di samping rawan konflik? Tulisan ini mencoba mencermati konteks tanah surat ijo beserta eksesnya dari sudut kesejarahan dengan bantuan konsep ilmuilmu sosial/hukum untuk mendapatkan suatu bentuk pemahaman yang bisa digunakan untuk mendukung upaya mencari resolusi konflik tanah surat ijo.

\section{B. Tata Kelola Tanah Negara di Surabaya}

Luas seluruh tanah negara' ${ }^{1}$ ang dikelola Pemerintah Kota Surabaya mencapai 14.963.717,29 m² atau 1.496,37 hektare. Sebagian tanah negara yang termanfaatkan untuk permukiman berlegalitas IPT atau tanah surat ijo mencapai tanah seluas $8.275 .970,28 \mathrm{~m}^{2}$ atau 827,60 hektare atau sekitar $55,31 \%$ dari seluruh luas tanah negara yang dikelola Pemerintah Kota Surabaya.

Selebihnya masih belum/tidak berstatus IPT, yakni seluas 5.980.963,47 $\mathrm{m}^{2}$ atau 598,10 hektare atau 44,69\% dari luas tanah negara yang ada; dan tidak selalu berupa lahan kosong tanpa bangunan, melainkan juga tanah yang dihuni warga yang belum/tidak melaporkan diri ke Dinas Pengelola Bangunan dan Tanah (DPBT) Kota Surabaya. ${ }^{2}$ Di samping itu, juga berbentuk fasilitas umum (fasum) komersial seperti pasar, rumah sakit, pertokoan, hotel, mall; dan fasilitas sosial (fasos) seperti taman kota, jalan, boezem, dan lain-lain yang non-komersial.

Tanah-tanah surat ijo itu tersebar di 26 kecamatan dari 31 kecamatan yang ada. Kecamatan yang memiliki tanah surat ijo terluas yakni Kecamatan Gubeng (Surabaya Selatan) seluas

${ }^{1}$ Tanah Negara adalah tanah yang dikuasai oleh negara, bukan dimiliki negara. Secara keseluruhan, tanah negara di Surabaya berasal dari konversi tanah bekas hak barat, baik bekas tanah eigendom Gemeente Surabaya maupun bekas tanah partikelir (particuliere landerijen). Menjadi tanah negara sebagai konsekuensi atas pemberlakuan UU No. I Tahun 1958 tentang Penghapusan Tanah Partikelir, dan pemberlakuan UUPA i96o.

${ }^{2}$ Hunian di atas tanah negara yang belum/tidak berlegalitas IPT biasa disebut "tanah surat putih", karena warga yang bersangkutan hanya diberi surat keterangan tinggal yang berwarna putih. Pemegang surat putih lebih beruntung karena belum/tidak terkena beban retribusi, hanya dibebani PBB. Oleh karena itu, mereka itu memilih "tiarap" tidak mendaftarkan tanahnya untuk menjadi tanah IPT. 
1.923.767,44 $\mathrm{m}^{2}$ (192,38 hektare), disusul Kecamatan Wonokromo (Surabaya Selatan) seluas 1.147.179,30 $\mathrm{m}^{2}$ (114,72 hektare). Di tingkat kelurahan, diantara 163 kelurahan ada 88 kelurahanyang memiliki tanah surat ijo. Kelurahan yang memiliki tanah surat ijo terluas yakni Kelurahan Ngagelrejo (Kecamatan Wonokromo) yakni 683.129,51 m² (68, $31 \mathrm{Ha})$, disusul kelurahan Baratajaya (Kecamatan Gubeng) seluas 650.625,23 $\mathrm{m}^{2}(65,06)$.

Di dalam dokumen DPBT Kota Surabaya tanah negara dikelompokkan berdasarkan status tanah seperti Hak Pakai (HP), Hak Pengelolaan Lahan (HPL), tanah Eigendom, tanah Besluit (pembelian pada zaman Belanda), hasil pengadaan Panitia Pengadaan Tanah untuk Negara (P2TUN), dan Tanah Negara Lain-lain (TNLL). Tentang luas tanah negara per status hak atas tanah itu selengkapnya ada pada tabel berikut.

Tabel 1. Luas Tanah Negara per Jenis Status Hak Atas Tanah 2008

\begin{tabular}{|l|r|}
\hline Status Hak Tanah & \multicolumn{1}{|c|}{ Luas $\left(\mathrm{m}^{2}\right)$} \\
\hline Besluit & $379.993,29$ \\
\hline Eigendom & $4.171 .741,00$ \\
\hline P2TUN & $622.669,50$ \\
\hline HP & $1.123 .494,50$ \\
\hline HPL & $7.687 .775,00$ \\
\hline TNLL & $978.044,00$ \\
\hline \multicolumn{1}{|c|}{ Jumlah } & $14.963 .717,29$ \\
\hline
\end{tabular}

Sumber: Diolah dari Daftar Inventarisasi Tanah yang Dikelola oleh Dinas Pengelolaan Tanah Daerah Kotamadya Daerah Tingkat II Surabaya (DPBT Kota Surabaya, 2008).

Di atas tanah surat ijo ada 48.200 persil, belakangan jumlahnya berkurang menjadi 46.116 persil. Tentang jumlah persil tidak identik dengan jumlah hunian, karena ditemukan banyak kasus yaitu satu persil untuk dua hunian atau lebih. ${ }^{3}$

${ }^{3}$ Ada beberapa kasus satu persil untuk dua atau lebih hunian. Biasanya, hal itu sebagai akibat dari pewarisan, ahli waris lebih dari satu. Mereka tidak melapor ke DPBT. Untuk membayar PBB dan retribusi dengan jalan patungan.
Tabel 2. Perkembangan Jumlah Persil

\begin{tabular}{|c|r|c|}
\hline Tahun & \multicolumn{1}{|c|}{$\sum$ Persil } & Keterangan \\
\hline 1996 & 38.425 & \\
\hline 2005 & 48.816 & \\
\hline 2006 & 46.965 & Terjadi penurunan \\
\hline 2007 & 47.347 & \\
\hline 2008 & 48.200 & \\
\hline 2012 & 48.116 & Terjadi penurunan \\
\hline
\end{tabular}

Sumber: Diolah dari Daftar Inventarisasi Tanah yang Dikelola oleh Dinas Pengelolaan Tanah Daerah Kotamadya Daerah Tingkat II Surabaya (DPBT Kota Surabaya, 1996-2014).

Peningkatan jumlah persil sebagai akibat dari adanya penghuni baru tanah negara dan adanya upaya mendaftarkan diri warga penghuni "tanah surat putih” ke DPBT Kota Surabaya. Sedangkan turunnya jumlah persil (2006 dan 2012) sebagai akibat dari beberapa faktor, antara lain sebagai dampak dari pengalihan peruntukan tanah surat ijo, misalnya, yang semula kawasan hunian diubah menjadi kawasan fasilitas umum komersial, seperti mall, hotel, pasar, pertokoan, pergudangan, dan lain-lain; maupun menjadi fasum non-komersial seperti sekolah, rumah sakit, tempat ibadah, taman kota, dan lain-lain. Selain itu, juga sebagai akibat dari bergesernya status beberapa persil tanah surat ijo menjadi status hak milik warga ${ }^{4}$ dan juga semakin bertambahnya pemboikot retribusi.

Sistem pengelolaan tanah surat ijo ditandai dengan satu beban retribusi (di samping beban PBB) pada warga penghuninya yang besarannya ditentukan dalam peraturan daerah, seperti pada tabel berikut ini.

${ }^{4}$ Dengan demikian Pemkot Surabaya bertindak double standard, bahkan tripple standard dalam mengelola tanah negara untuk hunian warga. Ada yang distatuskan IPT (surat ijo), ada yang lolos menjadi tanah HM, dan ada surat putih (belum ber-IPT dan belum HM). Tanah HM dan tanah surat putih tidak dikenai beban retribusi. 
Tabel 3. Ketentuan Besaran Prosentase untuk Menghitung Besaran Retribusi IPT

\begin{tabular}{|c|c|c|c|c|c|}
\hline \multirow{3}{*}{ No. } & \multirow{3}{*}{$\begin{array}{l}\text { Klasifikasi Jalan } \\
\text { (m) }\end{array}$} & \multicolumn{3}{|c|}{ Peruntukan Tanah } & \multirow{3}{*}{ Keterangan } \\
\hline & & \multirow[b]{2}{*}{$\begin{array}{c}\text { Permukiman } \\
\text { (\%) }\end{array}$} & \multicolumn{2}{|c|}{ Fasilitas Umum } & \\
\hline & & & $\begin{array}{c}\text { Komersial } \\
\text { Biasa } \\
(\%)\end{array}$ & $\begin{array}{c}\text { Komersial Khusus } \\
\text { (Mall dan Hotel) } \\
(\%)\end{array}$ & \\
\hline 1 & I $\quad(>15 \mathrm{~m})$ & 0.200 & 0.50 & 3.33 & \\
\hline 2 & II $\quad(>12-15 \mathrm{~m})$ & 0.175 & 0.45 & 3.00 & \\
\hline 3 & III $(>8-12 \mathrm{~m})$ & 0.150 & 0.35 & 2.33 & \\
\hline 4 & IV $(>5-8 m)$ & 0.125 & 0.25 & 2.00 & \\
\hline 5 & $\mathrm{~V} \quad(<5 \mathrm{~m})$ & 0.100 & 0.20 & 1.33 & \\
\hline
\end{tabular}

Sumber: Diolah berdasarkan Perda Kota

Surabaya No. 13 Tahun 2013 tentang Pemakaian Kekayaan Daerah.

Berikut ini contoh penghitungan besaran retribusi yang ditanggung oleh warga penghuni tanah surat ijo di kawasan Bratanggede Kelurahan Ngagelrejo. Luas tanah $185 \mathrm{~m}^{2}$ di jalan selebar $6 \mathrm{~m}$ atau jalan kelas IV (lihat Tabel 3), dan harga NJOP tanah yang tertera pada surat SPPT-PBB sebesar Rp 1.147.00o,- per $\mathrm{m}^{2}$. Penghitungan besaran retribusi yaitu 0,125 X 185 x Rp 1.147.000,- sama dengan Rp 265.243,75. Besaran retribusi itu bergantung pada lokasi kelas jalan, luas tanah, dan besaran NJOP yang telah ditetapkan di dalam Surat Pemberitahuan Pajak Terhutang Pajak Bumi dan Bangunan (SPPT-PBB), semakin tinggi kelas jalan dan semakin luas tanah maka semakin tinggi pula besaran NJOP; berkonsekuensi pada semakin tinggi besaran nilai retribusi. Bahkan, di beberapa kawasan rumah hunian tanah surat ijo besaran retribusinya lebih tinggi dari pada besaran PBB, misalnya rumah-rumah hunian surat ijo di jalan Baratajaya, Ngagel Madya, Pucang Anom, Dukuh Kupang Barat, Dukuh Kupang Timur, dan lain-lain yang kelas jalannya di atas 12 m (Kelas I dan II).

Contoh hunian di atas terletak di jalan yang lebarnya di atas $15 \mathrm{~m}$ (Kelas I), maka besaran retribusi 0,200\% x 185 x Rp 1.147.000,- sebesar Rp 424.390,-. Jadi, hampir sama dengan besaran PBB (Rp 450.66o,). Oleh karena itu, di kalangan warga kota, tanah surat ijo biasa disebut "tanah berpajak dobel", manakala hunian yang dicontohkan di atas itu (bisa) bersertifikat HM, maka hanya dibebani PBB saja.

Adanya perbedaan yang signifikan tentang beban tanggungan keuangan per tahun antara warga pemukim tanah surat ijo dengan pemukim tanah hak milik (HM). Barangkali, perbedaan itu menjadi salah satu faktor (dari sekian banyak faktor) yang menimbulkan ketidakpuasan warga pemukim tanah surat ijo selama ini.

\section{Dampak Pemberlakuan IPT}

Penyebutan tanah ber-IPT sebagai tanah surat ijo itu berasal dari zaman kolonial, yakni zaman gemeente Surabaya. Kini, terjadi pergeseran makna di kalangan warga penghuni, tanah surat ijo berkonotasi sebagai bentuk ejekan pada warga penghuni, dan bersamaan itu juga sebagai bentuk pelampiasan rasa ketidakpuasan terhadap keberadaan surat IPT beserta konsekuensinya. Dipandang dari perspektif semiotik, konsep tanah surat ijo sebagai tanda (sign) memiliki makna secara konotatif, yakni fungsi yang tidak disengaja dan tersembunyi (latent) yang berada di balik makna nyata (denotatif).

Pertama, dari aspek sosial, status/derajat sosial warga penghuni tanah surat ijo dianggap lebih rendah daripada status warga kota pemilik tanah berstatus HM. Rasionalnya, warga penghuni tanah surat ijo sebagai rakyat Indonesia memiliki harapan/cita-cita yang belum terlaksana yakni kebutuhan untuk memiliki papan (tempat tinggal) secara legal, dalam hal ini pemilikan tanah hunian berstatus HM. Jadi, warga penghuni tanah surat ijo yang berada dalam kondisi "kurang/tidak beruntung” seperti itu bisa dimaknakan sebagai warga kota yang berstatus lebih rendah daripada warga kota yang memiliki tanah HM, atau pun, sebagai warga yang kurang/tidak sejahtera.

Kedua, dari aspek politik, posisi warga penghuni tanah surat ijo selalu menjadi objek politik siklus lima tahunan, yakni menjadi obyek sasaran para politisi untuk "berburu suara”. Biasanya, ketika menjelang pemilu calon legislatif (caleg) atau pun pemilihan kepala daerah (pilkada), para caleg/ calon walikota (cawali) menebar janji bilamana nanti terpilih akan berjuang melepas tanah hunian 
menjadi hak milik warga penghuni. Namun kenyataannya lain, sudah tiga kali pemilu caleg selama era reformasi (2004, 2009, dan 2014) dan pemilihan walikota Surabaya (2000, 2005, 2010, dan 2015), janji pembebasan para pemberi janji belum terlaksana, baik anggota DPRD Kota Surabaya, DPRD Provinsi Jawa Timur (dari Daerah Pilihan/ Dapil Surabaya), DPR RI (dari Dapil I Jawa Timur), maupun walikota Surabaya yang telah terpilih tidak sesegera mungkin mengupayakan pelepasan tanah surat ijo, akibat lebih banyak sibuk menangani urusan-urusan lain yang lebih penting. Jadi, warga tanah surat ijo selalu menjadi "bulan-bulanan" para politisi, ibarat "habis manis sepah dibuang".

Ketiga, dari aspek ekonomi, harga pasar tanah surat ijo tidak setinggi tanah berstatus HM, juga tidak bisa diagunkan ke bank-bank untuk meminjam uang, meskipun bisa diperkenankan untuk jaminan kredit, itu hanya oleh bank-bank tertentu, biasanya bank-bank milik pemerintah daerah, itupun melalui prosesyang lama menunggu terbitnya persetujuan/rekomendasi dari pihak Pemerintah Kota Surabaya. Untuk jaminan kridit hanya dihargai nilai bangunannya saja, sedang tanah tidak dinilai karena dianggap asset milik Pemerintah Kota Surabaya (Njo Anastasia, 2006).

Keempat, dalam perspektif budaya, warga penghuni tanah surat ijo yang nota bene sebagai warga kota kelas rendah, ada kecenderungan psikologisbaik disadari maupun tidak- sebagai pihak yang menderita rendah diri atau inferioritas bila dipersandingkan dengan warga kota yang memiliki tanah HM, atau bisa juga sebagai warga kota yang termarginalkan dalam tata pergaulan masyarakat yang demokratis, mungkin bisa diibaratkan sebagai warga yang belum seutuhnya diakui sebagai warga negara.

\section{PerspektifTeoretik}

Dalam perspektif Marxis, dinamika sejarah kehidupan manusia digerakkan oleh material (historis-materialism). Property merupakan salah satu bentuk materi yang dianggap sangat berharga dalam kehidupan manusia. Tidak bisa diingkari bahwa manusia selalu berupaya mendapatkan materi, bahkan, tidak jarang terjadi konflik, baik antar individu, antar kelompok/negara, maupun antara individu versus kelompok/negara. Konteks konflik tanah surat ijo terjadi akibat adanya kepentingan (interest) warga untuk memiliki properti dalam bentuk tanah. Sementara itu, Pemkot Surabaya menganggap tanah negara itu sebagai asetnya, kedua belah pihak sama-sama merasa sebagai pihak yang paling berhak atas tanah surat ijo.

Dalam perspektif Marxis juga dinyatakan bahwa perkembangan/perubahan masyarakat ditentukan oleh faktor produksi (Nezar Patria dan Andi Arief 1999, 25). Sedang pihak-pihakyang bermain dalam perkembangan/perubahan itu adalah kelas pemilik modal dan kelas pekerja, Di dalam kerangka materialisme historis itu konteks tanah surat ijo boleh kiranya dapat dipandang bahwa Pemkot Surabaya bertindak sebagai pemilik modal, sementara warga penghuni sebagai pekerja, dan retribusi sebagai bentuk eksploitasi. Barangkali ada benarnya jika para pejuang surat ijo menyatakan bahwa retribusi dianggap sebagai bentuk pemerasan (PMPMHMT 2003), UUPA mengajarkan melarang segala bentuk pemerasan di dalam penguasaan/pemilikan tanah.

Negara, dalam hal ini Pemkot Surabaya berperan ganda, sebagai perumus suprastruktur dan sebagai pemain di ranah basic-structur. Peranganda itu menimbulkan kemudahan untuk melanggengkan penguasaan tanah negara dan juga melanggengkan proses penghisapan, yakni melalui produk legislasi yang mendukung sinambungnya sistem tanah surat ijo. Perda dibuat sedemikian rupa sehingga meyakinkan semua pihak bahwa PemkotSurabaya sebagai pemilik sah atas asset tanah surat ijo. ${ }^{5}$

\footnotetext{
${ }^{5}$ Di dalam perda-perda yang dibuat dari waktu ke waktu selalu terjadi penyempurnaan konsep tanah surat ijo, semula tanah sewa, barang milik daerah, kekayaan daerah, dan terakhir aset milik Pemkot Surabaya.
} 
dilihat dari sudut pandang kaum Marxian, di dalam konteks tanah surat ijo itu negara ikut berperan menjadi pemilik faktor produksi atau sebagai kelas borjuis. ${ }^{6}$ Keikutsertaan Pemkot Surabaya dalam ranah basic-structur itu telah menyeret negara berhadapan langsung dengan rakyat, baik dalam situasi/kondisi kondusif maupun konflik. Peran ganda seperti itu tidak lazim, negara tidak dibenarkan berperan sebagai borjuasi, Jika negara harus berperan dalam basic structur, harus diserahkan pada badan hukum yang bergerak di ranah komersial, misalnya BUMN/BUMD dan pihak swasta.

Selanjutnya, tindakan perlawanan yang dilakukan warga pemukim itu dalam perspektif strukturasi Giddens, bisa dinyatakan sebagai tindakan voluntair dan kepeloporan (agency) sekelompok orang actors atau agents (Anthony Giddens 1984; Philip Cassell ed. 1993, 92-93) yang kemudian diikuti oleh warga penghuni lainnya, walaupun tidak seluruh penghuni ikut serta secara aktif.

Keikutsertaan sebagian besar warga penghuni tanah surat ijo dalam perlawanan bervariasi tingkat keterlibatannya (Wawancara dengan Bambang Sudibyo, 2013), yakni terlibat aktif, memberi dukungan saja, dan yang apatis. Tipe warga yang terlibat aktif yakni yang ikut di dalam aksi-aksi massa, memboikot retribusi, rapat-rapat rutin, menjadi pengurus organisasi, hingga aktif dalam perjuangan di bidang ligitasi/peradilan. Tipe kedua, yang terlibat secara tidak langsung, yakni hanya memberikan bantuan (misalnya dana) untuk perjuangan namun tidak memboikot retribusi. Tipe ketiga yang apatis hanya melihat/mendengar saja dan tetap membayar retribusi. Secara umum, seluruh warga penghuni tanah surat ijo mendukung perjuangan mendapatkan status hak milik atas tanah huniannya, karena bila perjuangan berhasil, seluruh warga penghuni ikut diuntungkan.

\footnotetext{
${ }^{6}$ Peran negara sebagai suprastruktur berkewajiban menjaga keseimbangan di dalam interaksi/dialektika antara dua pihak di ranah basic-structur, yakni antara kelas pemilik faktor produksi dan kelas pekerja.
}

Pola dan karakteristik gerakan perlawanan warga penghuni tanah surat ijo dilakukan secara terorganisasi, seperti Gerakan Anti Surat Ijo Surabaya (Geratis) dan Gerakan Pejuang Hapus Surat Ijo Surabaya (GPHSIS), yang kemudian disatukan menjadi Perkumpulan Masyarakat Peserta Meraih Hak Milik Tanah (PMPMHMT) dengan Akte Pendirian No. 6 Tanggat 10 September 2003 (PMPMHMT 2003, 2). Karakteristik keanggotaan organisasi bercorak heterogen, tidak dibatasi oleh profesi, agama, etnik, golongan, kelas sosial, tingkat pendidikan, jabatan, penghasilan, dan lain-lain. sebagai organisasi yang prural, bukan juga organisasi seperti dalam gerakan ratu adil yang digerakkan seorang pemimpin tradisional (Sartono Kartodirdjo, 1984). Solidaritas keanggotaanya terbangun secara alamiah lahir dari kesadaran sosial (social soul) rasa senasib dan sepenanggungan; senasib karena sama-sama tinggal di atas tanah surat ijo, dan seperjuangan untuk mendapatkan sertifikat hak milik atas tanah, ${ }^{7}$ dalam konsep Robert E. Park (Muhammad Rivai, 2015) sebagai urban community yang merasa tidak puas yang kemudian melakukan struggle for existence.

Perlawanan warga penghuni itu bisa dianggap sebagai pilihan rasional (rational choice) demi mencapai tujuan yang didambakan bersama (Hans O. Melberg 1993). Pengalaman-pengalaman kegagalan upaya warga penghuni dalam menyertifikatkan tanah huniannya sebelum sampai di Kantor Pertanahan Kota Surabaya-akibat tidak pernah mendapatkan rekomendasi dari DPBT Kota Surabaya-telah menimbulkan rasa ketidakpuasan dan kekecewaan, bahkan kejengkelan di kalangan warga penghuni. Pada umumnya, ketidakpuasan yang berlangsung lama bisa menjadi faktor utama bagi timbulnya perlawanan (Kuntowijoyo 2008, 3739). Perlawanan warga penghuni itu adalah aksi

7 Di dalam konsep aktivis/pejuang surat ijo dikenal dengan "satu tekad, sepikiran, sehati, dan seperjuangan untuk memperoleh hak milik atas tanah". 
yang menurut Max Weber (1996) dimotivasi oleh tujuan rasional (end rational action) yakni rasionalitas ingin memperoleh hak milik atas tanah (land ownership). Boleh jadi, HM itu merupakan tujuan akhir sekaligus motivasi utama warga penghuni melakukan perlawanan, dasar perjuangan juga jelas yakni Keputusan Presiden (Keppres) No. 32 Tahun 1979, diatur bahwa tanah hasil konversi hak Barat bisa diajukan untuk disertif ikasikan secara HM oleh penghuninya, hal tersebut didasarkan pada Pasal 4 dan 5 sebagai berikut.

"Tanah-tanah Hak Guna Usaha asal konversi hak Barat yang sudah diduduki oleh rakyat dan ditinjau dari sudut tata guna tanah dan keselamatan lingkungan hidup lebih tepat diperuntukkan pemukiman atau kegiatan usaha pertanian, akan diberikan hak baru kepada rakyat yang mendudukinya." (Pasal 4)

"Tanah-tanah perkampungan bekas Hak Guna Bangunan dan Hak Pakai asal konversi hak Barat yang telah menjadi perkampungan atau diduduki rakyat, akan diprioritaskan kepada rakyat yang mendudukinya setelah dipenuhinya persyaratanpersyaratan yang menyangkut kepentingan bekas pemegang hak tanah." (Pasal 5)

Berdasarkan uraian di atas, dinyatakan bahwa konflik tanah surat ijo bukan sekadar akibat perbedaan persepsi terhadap keberadaan tanah surat ijo, sebagaimana dikemukakan oleh para peneliti sebelumnya (Binsar Simbolon dkk., 2008), melainkan sebuah dinamika sosial yang terjadi akibat motivasi/kepentingan kelompok yang memiliki tujuan rasional. Nampaknya, konflik tidak akan berakhir sebelum warga penghuni bisa mencapai tujuan mendapatkan status hak milik atas tanah huniannya. Di lain pihak Pemerintah Kota Surabaya juga tidak akan bisa nyaman karena kinerjanya terus terganggu selama konflik belum berakhir. Bisa dinyatakan bahwa mempertahankan keberadaan sistem tanah surat ijo ibarat memelihara api dalam sekam.

Perbedaan persepsi tidak selalu senantiasa berlanjut pada tingkat konflik/sengketa, perbedaan persepsi, tidaklah sulit untuk menyatukan kesepahaman di antara dua pihak yang tengah konflik. Konflik tanah surat ijo lebih terkait dengan keberadaan tanah sebagai modal dasar kehidupan manusia dalam bermasyarakat, yakni tanah untuk hunian. ${ }^{8}$ Di dalam masyarakat, khususnya Jawa, pemilikan tanah merupakan salah satu tolok ukur tingkat prestise seseorang dalam masyarakat. Artinya, seseorang warga baru diakui sebagai “orang” (Jawa: diuwongke) oleh masyarakatnya ketika yang bersangkutan sudah memiliki tanah hunian secara legal.

\section{E. Program Pelepasan Tanah Surat Ijo}

Salah satu dampak atas adanya beberapa tekanan dari warga penghuni semenjak awal era reformasi (1999), yakni timbulnya komitmen pelepasan tanah surat ijo oleh Pemerintah Kota Surabaya kepada warga penghuni, misalnya yang dilakukan oleh Walikota Bambang D.H. pada 2007 sempat melakukan konsultasi kepada Kepala BPN RI kala itu, Joyo Winoto. Hasilnya, yakni perlunya ditetapkan beberapa syarat tentang tanah yang boleh dilepaskan, seperti hanya tanah yang digunakan sebagai hunian, maksimal luasnya 200 $\mathrm{m}^{2}$, dan letaknya berada di jalan yang lebar maksimal lima meter (Jawa Pos 11 Februari 2012). Namun, komitmen tersebut belum terlaksana akibat masih menunggu hasil Putusan Pengadilan Negeri Surabaya pada 2007 atas gugatan warga.

Pada tahun 2011, Realisasi atas janji itu, sudah mulai disusun naskah akademik pelepasan tanah surat ijo oleh tim khusus pelepasan yang dibentuk oleh Walikota Surabaya (Jawa Pos 12 Februari 2011), setelah Pemkot Surabaya memenangkan perkara berdasarkan Kasasi MA Nomor 471K/Pdt/2011 tanggal 8 September 2011. Sesuai dengan arahan

${ }^{8}$ Pemilikan tanah hunian menimbulkan prestise seseorang di dalam masyarakat (Jawa). Seseorang dianggap ada/sukses sebagai manusia seutuhnya manakala yang bersangkutan sudah memiliki tanah hunian secara legal atau berstatus HM. 
walikota kepada Tim, upaya pelepasan hendaknya dilakukan secara ekstra hati-hati di dalam merumuskan Raperda (rancangan peraturan daerah) pelepasan tanah surat ijo. Ada yang bekas tanah eigendom, ada bekas tanah hak opstal, ada bekas tanah hak erfpacht atas nama gemeente maupun swasta (Ali Achmad Chomsah 2004), agar di kelak kemudian hari tidak timbul konflik/sengketa baru.

Beberapa anggota legislatif menyarankan agar secepatnya dilakukan pelepasan, misalnya anggota DPRD Kota Surabaya yang tergabung dalam komisi C DPRD Kota Surabaya, memperjuangkan pelepasan tanah surat ijo dengan persyaratan yang tidak memberatkan warga penghuni, termasuk Menteri ATR sempat menyentil Pemkot (jpnn.com 19 September 2014). Hingga tahun 2014 baru dicapai Peraturan Daerah No. 16 Tahun 2014 tentang Pelepasan Tanah Aset Pemerintah Kota Surabaya. Beberapa point persyaratan pelepasan yang sudah dirumuskan antara lain:

a) Luas tanah maksimal $250 \mathrm{~m}^{2}$

b) Sudah dihuni selama minimal 20 tahun

c) Surat IPT masih berlaku dan aktif membayar retribusi

d) Bila memiliki dua bidang tanah, hanya satu yang boleh diambil

e) Tanah yang boleh dilepas hanya untuk perumahan/hunian

f) Warga wajib membayar kompensasi kerugian negara sebesar nilai NJOP tanah kepada Pemkot Surabaya

Di dalam persyaratan terakhir itu (point "f") masih terjadi perdebatan/ketidaksepakatan antara pihak pemerintah kota dengan warga penghuni, warga penghuni menghendaki besaran kompensasi di bawah harga NJOP (Nilai Jual Objek Pajak) atau bila perlu gratis, sebab kebanyakan warga telah menghuni tanah sudah lebih dari 20 tahun, yang bermakna bahwa yang bersangkutan beritikad baik pada tanah dan tidak dipermasalahkan oleh masyarakat hukum adat dan desa/kelurahan (Pasal 24 Ayat 2 PP No. 24 Tahun 1997).
Harga NJOP tanah di kota Surabaya bisa dibilang sangat tinggi, harga minimal NJOP tanah di klasifikasi jalan terendah, yakni klasifikasi Vyang lebarnya di bawah 5 meter (Perda Kota Surabaya No. 2 Tahun 2013) sebesar satu juta rupiah per meter persegi, maka harga NJOP terendah satu bidang tanah surat ijo (yang biasanya seluas sekitar 200 $\mathrm{m}^{2}$ ) sebesar dua ratus juta rupiah. Bilamana diwajibkan membayar kompensasi sebesar harga NJOP, maka sebagian besar warga penghuni masih keberatan, karena tanah surat ijo yang berada di kelas jalan yang lebih tinggi atau lebih lebar, nilai NJOP-nya tentu lebih tinggi. Pada kenyataannya, sebagian besar warga penghuni tanah surat ijo terdiri atas warga kebanyakan, kelas menengah ke bawah. Berdasarkan faktor kondisi seperti itu, program pelepasan berdasarkan perda di atas akan mengalami hambatan, bahkan jalan buntu. Hingga kini, belum/tidak ada seorang pun warga penghuni tanah surat ijo yang mengajukan permohonan sertifikasi (Jawa Pos, 18 Agustus 2015).

Anggapan sebagian besar warga penghuni, makna program pelepasan tanah surat ijo itu yakni pembebasan total tanpa embel-embel kompensasi, jikapun ada, besarannya tidak senilai harga NJOP tanah dan hanya sekadar biaya administrasi penyertifikatan tanah, atau dengan istilah di kalangan pejuang surat ijo sebagai "dana partisipasi pembangunan" yang nilai besarannya di bawah NJOP tanah (Wawancara dengan Supadi HS 15 Maret 2015).

Menurut Bagir Manan (1992, 14) ada tiga landasan yang perlu dipenuhi sebagai syarat demi kualitas suatu peraturan, yakni landasan filosofis, yuridis, dan sosiologis. Sedang menurut Jimly Asshiddiqie (2006, 170-174) ditambah dua syarat lagi yakni landasan politis dan administratif. Berdasarkan pendapat dua pakar hukum itu, Perda No. 16 Tahun 2014, bisa dinyatakan sebagai peraturan yang kurang/tidak berkualitas, karena tidak terpenuhinya salah satu persyaratan yang ada, yakni landasan sosiologis, landasan yang berkaitan 
dengan kenyataan empiris yang ada/hidup dalam masyarakat; seperti kondisi sosial ekonomi, kecenderungan aspirasi, kebutuhan, cita-cita, harapan masyarakat selaku warga yang tinggal di atas tanah surat ijo. Namun, diakui maupun tidak diakui, Perda No. 16/2014 merupakan satu bentuk nyata komitmen Pemerintah Kota Surabaya dalam upaya memenuhi rasa keadilan warganya, minimal sebagai langkah awal yang positif dalam menuju tercapainya resolusi konflik tanah surat ijo.

\section{F. Resolusi Alternatif}

Pemberlakuan Perda di atas menunjukkan adanya semangat pemerintah daerah untuk mewujudkan keadilan dan kesejahteraan rakyat sebagaimana tertera dalam Pembukaan dan Pasal 33 UUD 1945. Oleh karena itu perlu ditindaklanjuti langkah resolutif berikutnya, alangkah baiknya semua persoalan ditempatkan pada porsinya, sesuai papan dan empan-nya. akan lebih legal/ konstitusional manakala kewenangan yang telah dilimpahkan/didelegasikan pemerintah daerah itu diserahkan kembali kepada pihak yang dulu telah memberikan limpahan wewenang, yakni negara. Di dalam kerangka itu, pihak yang berkompeten/ berkapasitas dan sebagai pemberi status hak atas tanah adalah Kementerian Agraria dan Tata Ruang/ BPN, melalui institusinya yakni Kantor Pertanahan di tingkat Kabupaten/Kota dan/atau Kantor Wilayah BPN di tingkat Provinsi. ${ }^{9}$

Ada mekanisme alternatif non ligitasi untuk menuju tercapainya resolusi konflik yang bisa mewujudkan win-win solution, yakni mekanisme Alternatif Penyelesaian Sengketa (APS) atau Alternative Dispute Resolution (ADR) yang bisa dicoba ditempuh (Maria S.W. Sumardjono 2002, 189; Arie

9 Untuk pemberian status hak milik atas tanah non pertanian di bawah $3.000 \mathrm{~m}^{2}$ merupakan kewenangan Kantor Pertanahan Kabupaten/Kota. Sedang urusan pemberian status hak milik tanah non pertanian di atas $3.000 \mathrm{~m}^{2}$ hingga $10.000 \mathrm{~m}^{2}$ ditangani oleh Kanwil BPN Provinsi.
S. Hutagalung, 2005, 376). Di dalam kerangka itu secara mutlak diperlukan campur tangan Negara, artinya, negara harus turun tangan menjadi prakarsa sekaligus mediator/arbitrator yang cerdas dan arif dalam proses penyelesaian konflik melalui mekanisme APS/ADR. Negara bisa menawarkan kepada para pihak, apakah arbitrer diperankan oleh Kementerian Agraria dan Tata Ruang/BPN atau bisa juga dipilih lembaga yang professional/independen, misalnya Badan Arbitrase Nasional Indonesia (BANI), atau pun lainnya (Arbitrase Center di http:/ /www.baniarbitration.org/ina/procedures.php).

Dasar pemberlakuan status HPL (Boedi Harsono 1968) adalah Pasal 33 Ayat 3, yang menyiratkan makna bahwa negara "menitipkan" kewenangan mengelola tanah negara untuk sebesar-besarnya kemakmuran rakyat (Maria S.W. Soemardjono 2007; Urip Santoso 2012). Jadi, posisi Pemkot Surabaya terhadap tanah berstatus HPL lebih merupakan semacam hak administratif daripada memanfaatkan untuk memperoleh profit, jelaslah tanah surat ijo bukan tanah milik pemerintah daerah (Hukumonline.com 2015; Republika, 15 Januari 2015). Pemegang HPL memang berwenang memanfaatkan tanah negara, namun tujuan utamanya yakni untuk memenuhi rasa keadilan/ kesejahteraan, terutama pihak ketiga yang berada di sekitar atau di atas tanah tersebut (Soemardijono 2005; Elita Rahmi 2010, 349-359).

Sebenarnya konflik tanah surat ijo tidak perlu terjadi, atau pun tidak berlama-lama. Kedua belah pihak tidak perlu bersitegang beradu otot/argumen memperebutkan status hak atas tanah negara, atau pun saling mengklaim sebagai pihak yang paling berhak, karena secara yuridis kedua belah pihak bukan pemilik tanah. Pemkot sebagai pihak yang penerima limpahan kewenangan mengelola, sedang warga penghuni sebagai pengguna. Sejatinya, kedua belah pihak (kalau boleh) "bukan apa-apa dan bukan siapa-siapa" terhadap tanah surat ijo. Apalagi terhadap tanah negara yang masih asli berstatus eigendom. 
Dalam konteks di atas, semestinya Pemkot tidak bisa semena-mena terhadap "barang titipan" negara, baik hanya sebatas mengklaim (Jawa: ndhaku) tanah HPL sebagai barang milik daerah maupun bertindak melepas/memindahtangankan. Pemkot tidak bisa serta merta sekehendak hati secara otonom melepaskan tanah surat ijo seolah sebagai pemilik, hingga menimbulkan situasi "negara dalam negara” (Ratna Djuita dan Indriayati 2011). Secara etika dan moral, penyelesaian konflik tanah surat ijo dalam bentuk pelepasan/pemindahtanganan harus dikembalikan kepada pemberi wewenang, yakni negara. Tentunya melalui lembaga yang berkompeten, Kementerian Agraria dan Tata Ruang dan/BPN.

Pemberlakuan Perda No. 16 Tahun 2014 tentang Pelepasan Tanah Aset Pemerintah Kota Surabaya (dan Peraturan Walikota No. 51 Tahun 2015), terkesan Pemkot Surabaya telah memposisikan diri sebagai pemilik tanah surat ijo, pada hal bukan pemilik, hanya sebatas pemegang HPL, yakni selaku pihak yang dipercaya secara administratif untuk mengelola tanah negara. Pemberlakuan Perda pelepasan seolah menunjukkan betapa biasnya pemahaman asal-usul status HPL. Atau, belum/ tidak disadarinya bahwa status HPL bukanlah HAT yang tidak bisa disetarakan dengan status HAT yang tersurat dalam UUPA. Dengan kata lain, kurang/ tidak disadarinya bahwa status HPL atas tanah negara itu berdasarkan Pasal 33 Ayat 3 UUD 1945 yang peruntukannya jelas-jelas untuk mencapai sebesar-besarnya kemakmuran rakyat. Juga, belum disadari (baca: ikhlas) bahwa status HPL bisa diubah atau pun ditingkatkan statusnya menjadi tanahyang berstatus HAT yang legal-konstitusional, dalam arti hak atas tanah yang diatur secara eksplisit dalam UUPA, dan demi terwujudnya kepastian hukum mengenai hak atas tanah untuk seluruh rakyat (Ahmad Nasih Luthfi dkk. 2010, 14).

Tanah HPL dapat dimaknai bahwa tanah surat ijo di Surabaya sebagai barang milik negara, sementara itu Pemerintah Kota Surabaya sebagai pengelola barang milik negara. Menurut UU No. 1 Tahun 2004 Pasal 45 Ayat 2 dinyatakan "pemindahtanganan barang milik negara/daerah bisa dilakukan melalui dijual, dipertukarkan, dihibahkan, atau disertakan sebagai modal Pemerintah setelah mendapat persetujuan DPR/DPRD" (Juga termaktub pada Pasal 54 Peraturan Pemerintah No. 27 Tahun 2014). Bila nilai barang milik negara itu bernilai lebih dari seratus milyar rupiah, harus mendapat persetujuan DPR (Pasal 55 PP No. 27 Tahun 2014). Berkaitan dengan program pelepasan tanah surat ijo yang luasnya mencapai 1.496,37 hektare, yang tentunya bernilai trilyunan rupiah, jauh di atas seratus milyar rupiah, semestinya memerlukan persetujuan DPR, setelah melalui usulan Menteri Keuangan selaku bendahara umum negara (Pasal 1 Ayat 2 PP No. 27 Tahun 2014).

Dalam perspektif seperti di atas, pemberlakuan Perda No. 16 Tahun 2014 itu bisa menimbulkan konotasi sebagai kekhilafan pemerintah daerah setempat dalam memaknai status HPL ataupun sudah paham tentang status HPL, pemberlakuan Perda tersebut mungkin bisa dimaknai sebagai bentuk kealpaan terhadap status/posisi negara selaku pemberi limpahan wewenang, dan mungkin terlupakan juga bahwa negara merupakan bentuk organisasi rakyat/bangsa Indonesia, yang mendapatkan mandat menguasai tanah dari rakyat (Lihat Pasal 2 dan Pasal 4 UUPA).

\section{G. Penutup}

Tanah surat ijo yang merupakan permukiman di atas tanah negara hasil konversi tanah hak Barat yang telah menimbulkan konflik antara warga pemukim versus Pemerintah Kota Surabaya merupakan fenomena unik yang sangat menarik untuk dicermati/dikaji lebih jauh. Keberadaan sistem tanah surat ijo itu sebagai varian pemanfaatan tanah HPL di Indonesia, namun esensinya tetap sebagai sistem sewa tanah yang lazim pada era kolonial.

Pemanfaatan tanah berstatus HPL hasil konversi tanah hak barat seperti di atas perlu ditinjau 
kembali keberadaannya, terutama yang diplot untuk permukiman rakyat, karena kurang/tidak sesuai dengan semangat mewujudkan keadilan/ kesejahteraan rakyat pada era kemerdekaan. Artinya, status HPL yang dilimpahkan kepada pemerintah daerah harus dibedakan dengan status HPL yang diajukan/diperoleh pihak badan usaha milik negara/daerah/swasta yang jelas-jelas didasari visi/ misi/tujuan komersial murni.

Konflik tanah surat ijo selayaknya menjadi skala prioritas utama penanganan, seyogyanya diselesaikan sesegera mungkin di bawah payung hukum UUPA dan UUD 1945, sebelum konflik berkembang semakin kompleks, menggurita, dan rumit. Di dalam kerangka mencapai resolusi itu, setidaknya diperlukan koordinasi tiga kementerian, yakni Kementerian Dalam Negeri, Kementerian Agraria dan Tata Ruang/BPN, dan Kementerian Keuangan Republik Indonesia.

Upaya penyelesaian konflik tanah surat ijo melalui jalur ligitasi yang cenderung menghasilkan keputusan menang-kalah (winner-losser) telah terbukti belum/tidak bisa menyelesaikan masalah konflik, oleh karena itu perlu dicoba penyelesaian melalui mekanisme non-ligitasi, misalnya APS/ ADR atau pun jalur politik/kebijakan.

Perlu digarisbawahi, bahwa program pelepasan/ pemindahtanganan tanah surat ijo ke tangan warga penghuni dapat menjadi sebuah momentum/ajang pembuktian secara nyata upaya negara dalam mewujudkan keadilan/kesejahteraan rakyat sesuai amanat konstitusi.

\section{Daftar Pustaka}

Anastasia, Njo, 2006, "Penilaian atas Agunan Kredit Berstatus Surat Hijau" dalam Journal of Management and Entrepreneurship Vol. 8, No. 2 (2006), 116-122, Faculty of Economy, Department of Management, Petra Christian University, Surabaya.

Blau, Peter 1964, Exchange and Power in Social Life, Wiley, New York.
Cassel, Philip (ed.), 1993, The Giddens Reader, Stanford University Press, California.

Chomsah, H, Ali Achmad, 2004, Hukum Agraria (Pertanahan) Indonesia, Jilid 1, Prestasi Pustaka, Jakarta.

Collins, Randall 1974, Conflict Sociology, Academic Press, New York.

Djuita, Ratna dan Indriayati, 2011, "Eksistensi dan Konflik Penguasaan Tanah Masyarakat Hukum Adat", dalam Jurnal Pertanahan, Menggagas RUU Pertanahan, Vol. 1 No. 1 November 2011, Pusat Penelitian dan Pengembangan BPN RI, Jakarta.

Gautama, Sudargo, 1990, Tafsiran Undang Undang Pokok Agraria, Penerbit PT. Citra Aditya Bakti, Bandung.

Giddens, Anthony 1984, The Constitution of Society, Outline of the Theory of Structuration, Polity Press, Cambridge.

Harsono, Boedi, 1968, Undang-Undang Pokok Agraria, Sedjarah Penjusunan Isi dan Pelaksanaannja, Djambatan, Djakarta.

Hukumonline.com 18 Juni 2015 "Ahli: Tanah HPL Bukan Aset Daerah" dalam situs http:// www.hukumonline.com/berita/baca/ lt558289b221708/ahli-tanah-hpl-bukan-asetdaerah.

Hutagalung, ArieS, 2005, Tebaran Pemikiran Seputar Masalah Hukum Tanah, Lembaga Pemberdayaan Hukum Indonesia, Jakarta.

Jawa Pos, 12 Februari 2011 "Pelepasan Surat Ijo Berbasis Kawasan, Pilihan Rasional Hindari Spekulan”.

Jawa Pos, 11 Februari 2012 "Tanah Surat Ijo Bisa Jadi Hak Milik, Dewan Usulkan dalam Raperda Barang Milik Daerah".

Jawa Pos 30 Juni 2014 "Rencana Pelepasan Tanah Surat Ijo di Surabaya, Warga Masih Berkeberatan Nilai Kompensasi”.

Jawa Pos, 18 Agustus 2015 "Pelepasan Surat Ijo tanpa Diskon, Warga Tak Mampu Bayar Pelepasan" JPNN.com 2014, "Menteri Fery Desak Wali Kota Surabaya Sertifikatkan Surat Ijo" dalam http:/ /www.jpnn.com/read/2014/11/19/270735/ Menteri-Fery-Desak-Wali-Kota-SurabayaSertifikatkan-Surat-Ijo-tanggal 19 November 2014 . 
, 2015 "Menteri Agraria Dukung Pelepasan Lahan Surat Ijo" dalam http:// www2.jawapos.com/baca/artikel/18481/ menteri-agraria-dukung-pelepasan-lahansurat-ijo, Tanggal 6 Juni 2015.

Kartodirdjo, Sartono 1984, Ratu Adil, Sinar Harapan, Jakarta.

Keputusan Presiden No. 32 Tahun 1979 tentang Pokok-pokok Kebijaksanaan dalam Rangka Pemberian Hak Baru atas Tanah Asal Konversi Hak-hak Barat.

Keputusan Presiden No. 34 Tahun 2003 tentang Pelimpahan Kewenangan Pemerintah Pusat ke Pemerintah Daerah (Kabupaten/Kota) tentang Pertanahan.

Kuntowijoyo 2008, Penjelasan Sejarah (Historical Explanation), Tiara Wacana, Yogyakarta.

Luthfi, Ahmad Nasih dkk, 2010, Kronik Agraria Indonesia, Memperluas Imajinasi Lintas Zaman, Sektor, dan Aktor, STPN dan Institut Sejarah Sosial Indonesia, Yogyakarta.

Melberg, Hans O, 1993, Three Argument about Rational Choice Theory in Sociology, http:// home.sol.no/hansom/papers/930520.htm.

Parlindungan, A.P, 1991, Landreform di Indonesia, Suatu Studi Perbandingan, Penerbit Mandar Maju, Bandung.

Patria, Nezar dan Andi Arief, 1999, Antonio Gramsci, Negara, dan Hegemoni, Pustaka Pelajar, Yogyakarta.

Pemkot. Surabaya 1969, Buku Himpunan Peraturanperaturan Daerah Kotamadya Surabaya, Pemerintah Kotamadya Surabaya.

Peraturan Daerah Kotamadya Daerah Tingkat II Surabaya No. 22 Tahun 1977 tentang Pemakaian dan Retribusi Tanah yang Dikelola oleh Pemerintah Kotamadya Daerah Tingkat II Surabaya.

Peraturan Pemerintah Republik Indonesia Nomor 27 Tahun 2014 tentang Pengelolaan Barang MilikNegara/Daerah.

PMPMHMT, 2003, Pemegang Surat Ijo telah Menjadi Korban Pembodohan, Penindasan, dan Pemerasan Pemerintah Kota Surabaya (Suatu Kajian Hukum Agraria, Sekretariat PMPMHMT, Surabaya.
Rahmi, Elita, 2010, "Eksistensi Hak Pengelolaan Atas Tanah (HPL) dan Realitas Pembangunan Indonesia" dalam Jurnal Dinamika Hukum Vol. 10, No. 3 September 2010, Fakultas Hukum Unsoed, Purwokerto.

Republika, 15 Januari 2015 "Yusril Sebut Gubernur Jateng Salah Persepsi”

Rivai, Muhammad, 2015, "Biografi dan Pemikiran Robert Erza Park” dalam http://ensiklo.com/ 2014/og/biografi-dan-pemikiran-robert-erzapark, Diakses pada 28 Oktober 2015.

Santoso, Urip, 2012, "Eksistensi Hak Pengelolaan dalam Hukum Tanah Nasional" dalam Jurnal Mimbar Hukum Volume 24, Nomor 2, Juni 2012, Fakultas Hukum UGM, Yogyakarta.

Sekarnadji, Agus, dkk, 2005, "Perlindungan Hukum bagi Pemegang Surat Hijau di Kota Surabaya”. Laporan Penelitian, LPPM Unair, Surabaya.

Simbolon, Binsar dkk. 2008, "Surat Hijau di Kota Surabaya, Provinsi Jawa Timur Laporan Penelitian, Sekolah Tinggi Pertanahan Nasional/STPN, Yogyakarta.

Soemardijono, 2006, Analisis Mengenai Hak Pengelolaan (HPL), Lembaga Pengkajian Pertanahan, Jakarta.

Sumardjono, Maria S.W, 2002, Kebijakan Pertanahan antara Regulasi dan Implementasi. Edisi Revisi, Penerbit Buku Kompas, Jakarta. 2007, "Hak Pengelolaan: Perkembangan, Regulasi, dan Implementasi” dalam Jurnal Mimbar Hukum, Edisi Khusus, September 2007, Fakultas Hukum UGM, Yogyakarta.

Soetojo, M. 1961, Undang-Undang PokokAgraria dan Pelaksanaan Land Reform. Untuk Dinas Tidak Diperdagangkan. Staf Penguasa Perang Tertinggi, Jakarta.

Spencer, Herbert, 1959, Principles of Sociology dalam file:///CI/INTERNET/NETSCAPE/ SPENCER.H, dikutip dari Robert Bierstedt, The Making of Society, pp. 253-273, Modern Library, New York.

Steele, R.M, 1980, Origins and Occupational Mobility of Livetime Migrants to Surabaya East Java. Vol. 1, A Thesis Submitted for the Degree of Doctor of Philosophy of The Australian National University. 
Suarapublicnews.net, 2014, "Adies Kadir Libas Priyo Budi Santoso di Dapil 1 Surabaya-Sidoarjo" dalam Suarapubliknews.net di situs http:// suarapubliknews.net/peristiwa-6/item/1827adies-kadir-libas-priyo-budi-santoso-di-dapil1-surabaya-sidoarjo. Tanggal 26 April 2014.

Surya Online 20 Januari 2016 "Warga Tanah Surat Ijo Mengaku Keberatan Membayar Kompensasi Sesuai NJOP”.

Tauchid, Mochammad, 1952, Masalah Agraria, Sebagai Masalah Penghidupan dan Kemakmuran Rakjat Indonesia, Jilid I dan II, Penerbit Tjakrawala, Djakarta.
Undang-Undang Republik Indonesia Nomor 1 Tahun 2004 tentang Perbendaharaan Negara. Verslag Der Stadsgemeente Soerabaja Over 1940, Deel 1, Algemeen Verslag, Soerabaja, 1 Juni 1941. Weber, Max, Basic Concepts of Sociology. Dikutip dari file internet: ///C!/INTERNET/ NETSCAPE/BASIC_CONCEPTS.html, Diakses pada 20 Januari 2001.

Wolff, Kurt. Trans, 1950, The Sociology of George Simmel, pp. 402-408, Free Press, New York. Dalam situs file///CI/INTERNET/NETSCAPE/ STRANGER.

Lampiran 1: Contoh SPPT PBB Rumah Hunian di Atas Tanah Surat Ijo

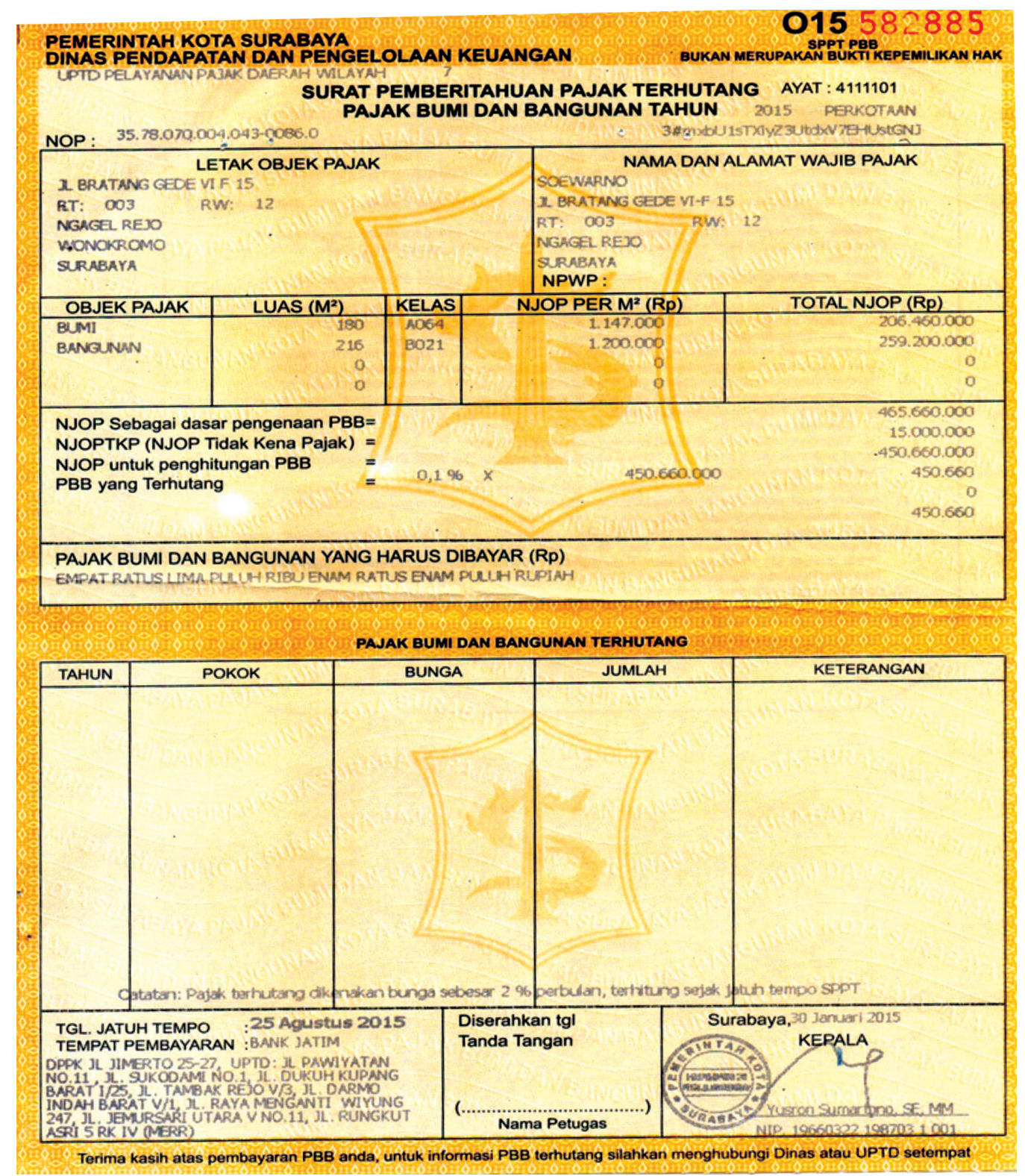

Sumber: Dokumen pribadi warga Bratanggede Kelurahan Ngagelrejo Kecamatan Wonokromo, Surabaya 
Lampiran 2: Contoh Bukti Pembayaran Retribusi Tanah Surat Ijo

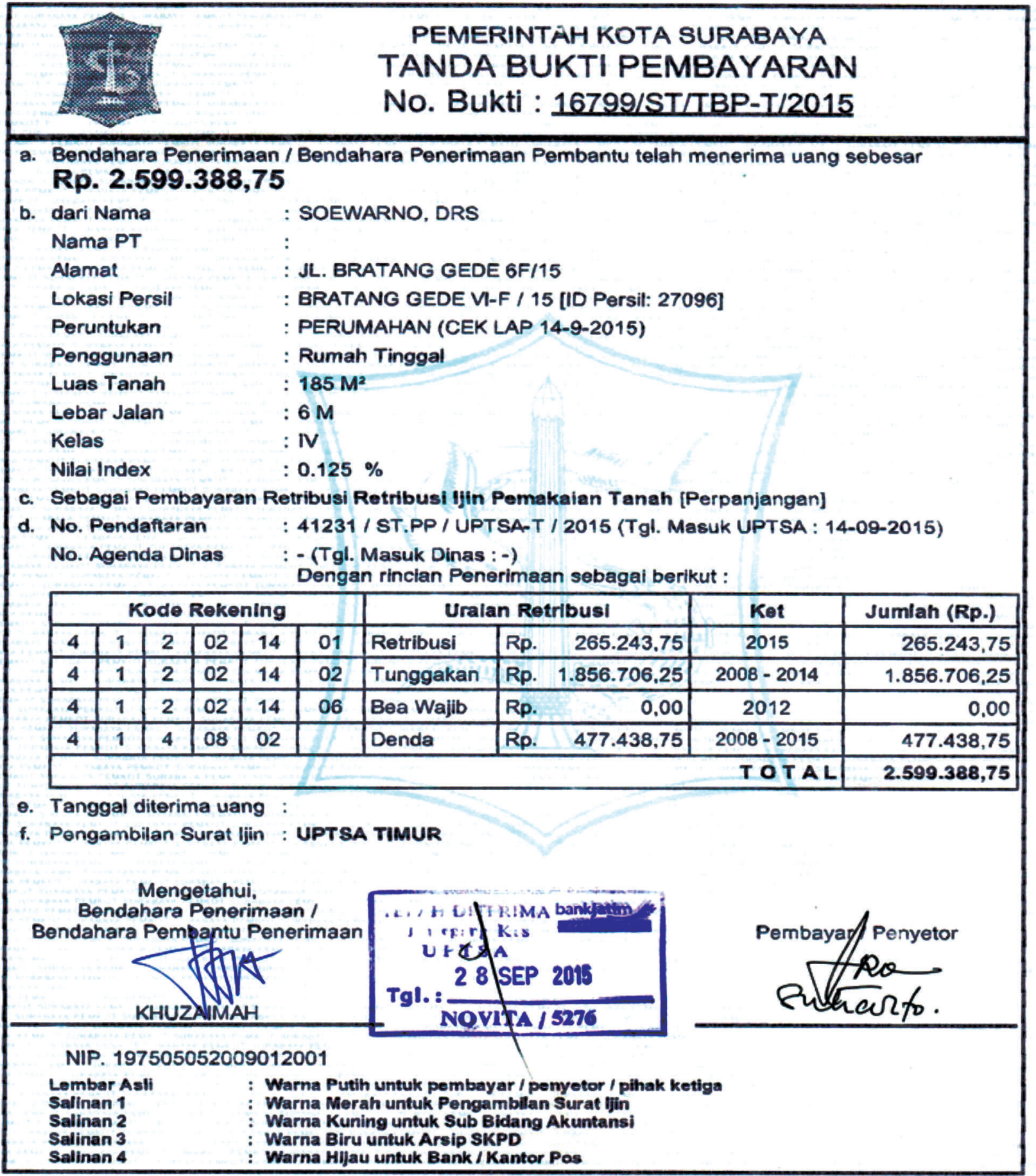

Sumber: Dokumen pribadi warga Bratanggede Kelurahan Ngagelrejo Kecamatan Wonokromo, Surabaya. 